\title{
EXPANDING ANALYTICAL CAPABILITIES OF THE RATIO ANALYSIS OF ENTITIES' SOLVENCY THROUGH CASH FLOWS
}

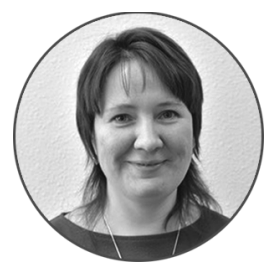

\section{Article history:}

Received 6 July 2017

Received in revised form

19 September 2017

Accepted 23 October 2017

Translated 16 March 2018

Available online 27 March 2018

JEL classification: G39, L25, L93

Keywords: solvency, current ratio, cash flow coverage ratio, credit rating

\author{
Lyubov' Yu. LASKINA \\ ITMO University, St. Petersburg, Russian Federation \\ risk05@mail.ru
}

\begin{abstract}
Importance The article studies ratios assessed through cash flows, i.e. cash flow ratio and interest coverage ratio, and their application to capture a more reliable and comprehensive view of the entity's solvency and financial sustainability.

Objectives The research examines cash flows of the entity as an additional source of information to manage corporate solvency.

Methods The research is based on financial statements of airport operators for the period spanning from 2011 until 2014. I also compare the cash flow coverage ratio and cash interest coverage ratio with traditional ratios, such as current ratio and interest coverage ratio respectively. Conducting a correlation analysis, I trace the nexus between the above pairs of ratios.

Results As the research proves, the current ratio and cash flow coverage ratio do not correlate strongly. Users should better use respective cash flow ratios to get more full and accurate information. Relying on their strong correlation, the cash interest coverage ratio can be applied to a greater extent to analyze the financial standing of entities.

Conclusions and Relevance As I conclude, if supplemented with the cash interest coverage ratio, the interest coverage ratio can not only provide a broader and deeper view of the entity's financial standing, but also be used to specify the credit rating of the entity. It will be more adequate and accurate to assign a credit rating on the basis of the cash interest coverage ratio since it allows for cash flow.
\end{abstract}

(c) Publishing house FINANCE and CREDIT, 2017

The editor-in-charge of this article was Irina M. Vechkanova Authorized translation by Irina M. Vechkanova

Doing business in today's world turning to the innovative development path, the Russian entities outright face the need to act and evolve under new circumstances. Living this period, they realize the sheer importance of being financially sustainable and healthy.

${ }^{\dagger}$ For the source article, please refer to: Ласкина Л.Ю. Расширение аналитических возможностей коэффициентного анализа платежеспособности предприятий на основе денежных потоков. Экономический анализ: теория и практика. 2017. Т. 16. № 11. С. 2145-2162.

URL: https://doi.org/10.24891/ea.16.11.2145
Entities attain an appropriate solvency if they are able to perform their payment obligations in a timely and adequate manner. This raises one of the crucial issues, which contemporary companies consider their first priority to address. Therefore, they should not only improve the solvency management process but also refine their methods for its analysis and evaluation.

Such procedures are applied by business proprietors and external users. If the entity is insufficiently solvent, this may cause the loss and waste of its own and raised 
resources, to say nothing about its publicity and reputation.

The concept of solvency is customarily linked to liquidity, i.e. the entity's ability to convert its assets into cash and satisfy current liabilities with it only [1]. The ratio analysis has gained traction in the modern practice of evaluating the solvency level. These are financial ratios and their assessment that still attract attention of many specialists, notwithstanding other techniques exist.

In Russia, the so called official ${ }^{1}$ and originally designed techniques (V.V. Kovalev², A.D. Sheremet with co-authors $^{3}$, N.P. Lyubushin and N.E. Babicheva ${ }^{4}$ ) are more in use, having just a different mix of underlying metrics. Relative indicators play a key role in this respect, with liquidity ratios prevailing.

Other ratios also shed light on the entity's ability to pay and repay. For example, the interest coverage ratio may be an additional metric describing the entity's ability to pay. SPARK is one of the largest databases providing comprehensive financial, statistical and other information on companies from various sectors. It also refers to this metric for purposes of solvency analysis. The interest coverage ratio is a sort of indicator measuring the likelihood of the entity's default. It is extremely important from perspectives of the solvency level. As mentioned in the research [2], the ratio shall exceed 1 to mean that the entity is able to repay interests in due time and manner.

As for the importance of the ratios to evaluate corporate solvency and make managerial decisions on

\footnotetext{
${ }^{1}$ Federal Law of the Russian Federation On Insolvency (Bankruptcy) of October 26, 2002 № 127-Ф3; Resolution of the RF Government On Approval of Financial Analysis Rules for Court-Appointed Administrators of June 25, 2003 № 367; Order of the RF Ministry of Economic Development On Approval of the Methods for the Federal Tax Services to Consider and Analyze the Financial Position and Solvency of Strategically Important Entities and Organizations of April 21, 2006 № 104.

${ }^{2}$ Kovalev V.V. Finansovyi analiz: metody i protsedury [Financial analysis: methods and procedures]. Moscow, Finansy i Statistika Publ., 2002, 559 p.

${ }^{3}$ Sheremet A.D., Saifulin R.S., Negashev E.V. Metodika finansovogo analiza [Financial analysis methods]. Moscow, INFRA-M Publ., 2001, $208 \mathrm{p}$.

${ }^{4}$ Lyubushin N.P., Babicheva N.E. [Analysis of methods for evaluating corporate financial standing]. Ekonomicheskii analiz: teoriya i praktika = Economic Analysis: Theory and Practice, 2006, no. 22, pp. 2-7. URL: https://cyberleninka.ru/article/v/analiz-metodik-po-otsenkefinansovogo-sotoyaniya-organizatsii (In Russ.)
}

finance, it is worth mentioning that it is not the assessment of relative indicators that becomes one of the principal steps in the procedure, but rather interpretation of the findings. The validity of the financial position assessment considerably depends on the quality of the conclusion inferred upon the assessment of the ratios.

I shall note that the ratio analysis entails some issues of assessing traditional solvency ratios [3-5]. The financial standing cannot be perennially assessed in an adequate way even if the resulting ratios are compared with standard ones. Furthermore, analyzing trends in financial ratios, users often overlook benchmarks or determine optimal bounds of the ratios, focusing only on their changes.

Zooming in the issues, it is noticeable that the comparison of the resulting ratios and their benchmarks comes across significant limitations since individual operational conditions are not taken into account [5]. The resulting ratios and their benchmarks are often difficult to compare since sectoral specifics is neglected. Rating agencies outside Russia set and release such benchmarks on a regular basis [4].

Moreover, the validity of the ratio analysis results also depends on initially available information used for evaluation purposes. However, financial reporting data do not necessarily assure the accuracy and reliability of information to describe the entity's financial position, solvency and liquidity. The reason is that financial reporting data tend to be unrelated (first of all, accounting revenue and profit) [6]. Users more often than not complain about their poor representative quality for further assessment and managerial decisionmaking on corporate finance since such data can be manipulated by owners and management in order to disguise the real situation. Furthermore, traditional ratios complicate a fair presentation of the financial positions due to distinctive valuation of assets and accrual accounting.

Specialists suppose that the matter of traditional ratios can be resolved if cash flow data are used inter alia. It is cash that measures all the financial relationships the entity enters into. Irregular and uneven proceeds and payments may engender some negative implications, thus undermining, say, liquidity, that is a solvency maintenance factor [7].

Please cite this article as: Laskina L.Yu. Expanding Analytical Capabilities of the Ratio Analysis of Entities' Solvency Through Cash Flows. 
Figures from cash flow statements are much more problematic to be manipulated since they rely upon cash flow, which is specific and real by nature, rather than conditional. This is the reason why cash flow figures lay the basis for some ratios, which elucidate the corporate financial position in a more complete and reliable manner (Table 1) [8].

Assuming that cash flows are used to assess cash flow ratios, users focus on the most liquid part of working assets - cash and cash equivalents. It also helps them look into the future financial situation. Hence some scholars suggested using cash flows to assess liquidity. Moreover, cash flows are more convenient to ensure higher precision of traditional ratios applied to financial analysis $[9,10]$. Therefore, for purposes of analyzing corporate solvency in a short run, some scholars suggest that users should compare such ratios as cash flow coverage ratio and current ratio, critical needs cash coverage ratio and quick ratio, cash interest coverage ratio and interest coverage ratio (Table 2).

I should note that, although foreign experts (I mean those ones outside Russia) do assess cash flow ratios, foreign literature does not specify the extent to which the given pairs of ratios correlate. Although the Russian specialists raise the question of applying such ratios more frequently, such ratios are almost out of use to evaluate and describe corporate financial standing.

To provide the rationale for cash flow ratios, I study to what extent the cash flow ratios and traditional ratios correlate in a solvency analysis.

In this case, I review such cash flow ratios as cash flow coverage ratio and cash interest coverage ratio. The assessment is based on figures of the Russian airport operators.

Relating to infrastructure, airport operations are fairly one of the key vessels of economy worldwide and nationwide. The condition of such sectors, their development and respective processes shape the competitiveness of national economies [11, 12]. The same idea is corroborated in the federal specialpurpose program ${ }^{5}$, which defines the transportation system development as a premise for implementing an innovative model of economic growth. The program

\footnotetext{
${ }^{5}$ Resolution of the RF Government On the Federal Special-Purpose Program, Development of Russia's Transport System (2010-2020), of December 5, 2001 № 848.
}

puts the development of aviation land infrastructure as one of the priority goals.

Airport operations become the subject of multiple studies in Russia not only because the transportation sector needs to be converted into an industry, which would be adequate to current needs and prospects of the national development, but more due to the fact that the quality and state of airport infrastructure leave much to be desired. Airports have been reducing in numbers for a long time. Currently, according to the Federal Air Transport Agency, there are 297 operational airports in Russia. As compared with the 1990s, as specialists note $[13,14]$, the number is four times as low as it used to be (Fig. 1).

The situation especially affected the regions where the availability and accessibility of transport drastically differs from that in the European part of Russia, though air flights are the only transportation option for some regions. The Siberian and Far Eastern Federal Districts are both cases in point.

While the number of airports are falling, ridership is observed to rise, thus causing wear and tear of fixed assets, which ranged from 40 to 80 percent in $2011^{6}$.

As the federal special-purpose program, Development of Russia's Transport System (2010-2020), the current circumstances inhibit a growth and use of transit capabilities, development of the common economic space in the country. Tremendous financial injections are needed to make the things going forward [15]. Therefore, to make development investments, most airports have to obtain substantial loans or search for external investors. Both options imply that airport operators shall maintain their solvency and stable financial position.

For analysis purposes, I selected twelve Russian airport operators from five federal districts within 2011 and 2014 inclusive.

These are

- AO Vnukovo International Airport (Moscow);

- OAO Volgograd International Airport;

- OAO Anapa Airport;

\footnotetext{
${ }^{6}$ Air transport review. Aviation Business Portal. URL: http://www.ato.ru/ (In Russ.)
} 


\section{- OAO Pobedilovo Airport (Kirov);}

- OAO Kazan International Airport;

- AO Ulyanovsk Airport;

- OAO Irkutsk International Airport;

- AO Tolmachevo Airport (Novosibirsk);

- OAO Omsk Airport;

- OAO Vladivostok International Airport;

- OAO Khabarovsk Airport;

- AO Yakutsk Airport.

As stated in reporting forms for 2011-2014 ${ }^{7}$, the above pairs of ratios were assessed per each company and analyzable year: current ratio $K_{\text {cur.lqdt }}$ and cash flow coverage ratio $K_{C F C R}$ (Table 3 ).

Few of the sampled companies have the current ratio within the generally advisable range of values, with the average value in the industry as a whole (from 1.2) . $^{8}$ This is evidence of a most challenging situation, when entities are unable to perform their current liabilities without any difficulties and using their available current assets. Regional airports were found to be exposed to the highest repayment risk (those ones operating in the Volga Federal District and Far Eastern Federal District).

As compared with the traditional current ratio, the cash flow coverage ratio, as a cash-based one, gives much more meager results. It means that entities virtually generate insufficient cash (or critically little).

However, the current ratio and cash flow coverage ratio mostly develop and change in a synchronized way in most cases (Fig. 9).

In the mean time, another situation can be seen. When one indicator rises, the other one changes in an opposite way (Fig. 3).

That is the reason why I conducted a correlation analysis and calculated Pearson's product-moment correlation coefficient and Spearman's rank correlation coefficient, tracing such an untypical trend among homogeneous values of coefficients behavior.

\footnotetext{
${ }^{7}$ Center for Corporate Disclosures. URL: http://www.e-disclosure.ru/ (In Russ.)

${ }^{8}$ Federal State Statistics Service. URL: http://www.gks.ru/ (In Russ.)
}

Spearman's rank correlation coefficient between the current ratio and cash flow coverage ratio amounts to 0.4097 , thus signifying a frail relation, albeit an existing one, between both ratios.

Similarly, I assessed correlation coefficients of the other pair of ratios to test to what extent the interest coverage ratio $K_{I V C}$ and cash interest coverage ratio $K_{C I C R}$ correlate (Table 4).

The interest coverage ratio of airport operators exceeds the average ratio of the other infrastructure-related industry - transport, being $4.25^{9}$. Values of the interest coverage ratio reveal some tendency. The lowest interest coverage ratio is observed in smaller regional companies (Pobedilovo Airport - Kirov) or those ones with a decline in operating profit (Vnukovo International Airport - Moscow). These are the airport operators which faced the toughest difficulties in repaying interests.

The cash interest coverage ratio is slightly higher than its traditional analogue (in most of the companies) and changes in the same way throughout the analyzable period (Fig. 4).

There are unusual cases indeed concerning the way the ratios change. For instance, the ratios of Vladivostok International Airport changed throughout the last year of the analyzable period in different directions, ranging from 0.73 to -17.38 of $K_{I V C}$ and from 6.27 to 8.53 of $K_{C I C R}$ (Fig. 5).

To get a more accurate view of the extent to which the interest coverage ratio and cash interest coverage ratio correlate, and understand the trends of their movement, I carry out a correlation analysis. According to the Chaddok scale, the pair of analyzable ratios has a strong positive relationship. When I additionally analyze the interest coverage ratio and cash interest coverage ratio by assessing Spearman's rank correlation coefficient, I find a strong direct relationship between the ratios. The rank correlation coefficient is 0.627 .

Therefore, the research reveals a frail correlation between the current ratio and cash flow coverage ratio.

\footnotetext{
${ }^{9}$ Laskina L.Yu. [Features of determination and estimation of financial leverage: Domestic and foreign experience]. Finansy $i$ kredit $=$ Finance and Credit, 2012, no. 38, pp. 55-61.

URL: https://cyberleninka.ru/article/v/osobennosti-opredeleniya-iotsenki-finansovogo-leveridzha-otechestvennyy-i-zarubezhnyy-opyt (In Russ.)
} 
Internal users and would-be investors may get more representative and reliable information by using the cash-based option from the other pair, i.e. cash interest coverage ratio and interest coverage ratio. As they demonstrate a close correlation, they enable certain users to guess that the cash interest coverage ratio has a broader scope of application to analyze the financial position of entities.

Some rating agencies are known to use the traditional interest coverage ratio as a tool to assign a credit rating to an entity, which characterizes its ability to timely repay interests and financial injections made by creditors and investors [16].

For example, as S\&P treats entities that hold borrowings made up of bank loans and have no credit rating, they assign the so called synthetic credit rating just on the basis of the interest coverage ratio (Table 5).

Moreover, the interest coverage ratio shows how many times for the reporting period the entity has managed to earn so as to repay interests and loans. However, it says nothing as to whether the entity has enough money to do so. It will definitely be more reasonable and reliable to assign a credit rating on the basis of the cash interest coverage ratio since it allows for the category of cash flow [17].

Assuming a close correlation between the traditional and cash flow ratios - interest coverage ratio and cash interest coverage ratio, it is possible to gauge an approximate range of the cash interest coverage ratio for large entities of a certain sector. Ranking the cash interest coverage ratio by value in the descending order and using Sturge's rule, I determine how many groups they make: $n=1+3.222 \lg N$

where $n$ stands for a number of groups;

$N$ is the number of observation points (values of the ratios);

$\lg N$ is the common logarithm of $N$.

Thus, I find out that the resulting range of values gives $n=5.56$, or $5-6$ groups. Breaking down the values into five ranges, I assign likewise a lower rating to a range with lower values (Table 6).

Applying the grouping method, I classify the sampled companies by their value of the cash interest coverage ratio into groups, which match the ranges of the given ratio for 2014 (Table 7). I do the same manipulations with the interest coverage ratio (Table 8).

Based on this distribution, I conclude that the entities has equally low credit ratings by cash interest coverage ratio and traditional interest coverage ratio, and, vice versa, high ratios make them eligible for better credit ratings [18]. Hence, the more often entities coincide by area of the same rating if grouped by a certain rating, the more complete and reliable the financial standing information. Should the entity mismatch the same group in terms of its rating, a more thorough study be needed. Relying upon the calculations, I conclude that if the interest coverage ratio is supplemented with the cash interest coverage ratio to evaluate corporate solvency, it will not only give a broader and deeper view of the financial standing and stability, but may be used to determine the entity's credit rating [19]. Investment opportunities of entities may be adequately evaluated if their credit ratings are specified in accordance with the international standards [20]. 
Table 1

Financial ratios of entities by cash flow analysis

\begin{tabular}{|c|c|c|}
\hline Ratios & Assessment Formula & Economic Substance \\
\hline Cash Flow to Debt Ratio & $\begin{array}{l}K_{C F D}=C F_{0} / T D L \\
\text { where } C F_{0} \text { is net cash flow from operations; } \\
T D L \text { is gross debt liabilities }\end{array}$ & $\begin{array}{l}\text { A predictor of financial inability to pay to evaluate the corporate } \\
\text { creditworthiness }\end{array}$ \\
\hline Dividend payout to CAPEX ratio & $\begin{array}{l}K_{\text {CAPEX }}=\left(D_{0}-D_{\text {paid }}\right) / \text { CAPEX } \\
\text { where } D_{\text {paid }} \text { is dividends paid; } \\
\text { CAPEX } X_{\text {total }} \text { is the amount of capital expenditures }\end{array}$ & $\begin{array}{l}\text { A metric showing the entity's ability to finance its future growth } \\
\text { through its operations. It is used to evaluate the entity's ability to } \\
\text { pay debts and dividends }\end{array}$ \\
\hline Cash-based Return on Assets & $\begin{array}{l}K_{C R O A}=\left(D_{0}+I_{\text {paid }}+T\right) / A \\
\text { where } I_{\text {paid }} \text { is interests paid; } \\
T \text { is taxes paid; } \\
A \text { is total assets }\end{array}$ & $\begin{array}{l}\text { A metric showing the ability of the entity's assets to generate } \\
\text { cash flows. It is used to check whether the accounting return is } \\
\text { secured with real cash proceeds }\end{array}$ \\
\hline
\end{tabular}

Source:[8]

Table 2

Comparison of traditional liquidity ratios and cash flow ratios

\begin{tabular}{ll}
\hline Ratio & Assessment Formula \\
\hline Current Ratio & Traditional Ratios \\
& $K_{\text {curlqdt }}=C A / C L$, \\
where $C A$ is current assets; \\
$C L$ is current liabilities
\end{tabular}

Source:[9]

Please cite this article as: Laskina L.Yu. Expanding Analytical Capabilities of the Ratio Analysis of Entities' Solvency Through Cash Flows. 
Table 3

Current ratio $K_{\text {cur.lqdt }}$ and interest coverage ratio $K_{N C}$ of airport operators, 2011-2014

\begin{tabular}{|c|c|c|c|c|c|c|c|c|}
\hline \multirow[t]{2}{*}{ Entity } & \multicolumn{2}{|l|}{2011} & \multicolumn{2}{|l|}{2012} & \multicolumn{2}{|l|}{2013} & \multicolumn{2}{|l|}{2014} \\
\hline & $K_{\text {cur.lqdt }}$ & $K_{I V C}$ & $\boldsymbol{K}_{\text {curl.lqdt }}$ & $K_{I V C}$ & $\boldsymbol{K}_{\text {cur.lqdt }}$ & $K_{I V C}$ & $K_{\text {cur.lqdt }}$ & $K_{I V C}$ \\
\hline Vnukovo International Airport & 8.62 & 0.79 & 18.17 & 3.4 & 9.5 & 0.9 & 9.54 & -0.13 \\
\hline Volgograd International Airport & 1.52 & 0.17 & 2.17 & 1.48 & 3.17 & 1.96 & 4.06 & 2.43 \\
\hline Anapa Airport & 21.88 & 5.91 & 1.78 & -0.04 & 5.27 & 0.78 & 4.88 & 0.51 \\
\hline Pobedilovo Airport - Kirov & 0.7 & -1.35 & 0.73 & -2.38 & 0.2 & -0.54 & 1.54 & -3.3 \\
\hline Kazan International Airport & 0.72 & -0.17 & 1.08 & -0.05 & 0.79 & 0.06 & 1.88 & -1.28 \\
\hline Ulyanovsk Airport & 0.99 & 0.39 & 0.3 & 0.7 & 10.45 & -1.04 & 0.7 & 0.21 \\
\hline Irkutsk International Airport & - & - & - & - & 1.36 & 1.37 & 1.78 & 1.07 \\
\hline Tolmachevo Airport & 1.43 & 1.12 & 1.1 & 0.85 & 1.62 & 1.46 & 3.86 & 2.85 \\
\hline Omsk Airport & 0.69 & 1.26 & 1.03 & 0.99 & 1.46 & 1.63 & 2.07 & 1.88 \\
\hline Vladivostok International Airport & 12.29 & 8.1 & 0.96 & 0.64 & 0.61 & 0.18 & 0.21 & 0.18 \\
\hline Khabarovsk Airport & 1.19 & 0.72 & 1.78 & 0.49 & 2.57 & 0.36 & 2.23 & 0.05 \\
\hline Yakutsk Airport & 0.88 & 0.43 & 1.3 & 0.68 & 1.72 & 0.57 & 1.71 & 1.62 \\
\hline
\end{tabular}

Source : Authoring

\section{Table 4}

Interest coverage ratio $K_{I V C}$ and cash interest coverage ratio $K_{\text {CICR }}$ of airport operators, 2011-2014

\begin{tabular}{lllllllll}
\hline \multirow{2}{*}{ Entity } & $\mathbf{2 0 1 1}$ & & $\mathbf{2 0 1 2}$ & & $\mathbf{2 0 1 3}$ & \multicolumn{2}{c}{$\mathbf{2 0 1 4}$} \\
\cline { 2 - 8 } & $\boldsymbol{K}_{\text {IVC }}$ & $\boldsymbol{K}_{\text {CICR }}$ & $\boldsymbol{K}_{\text {IVC }}$ & $\boldsymbol{K}_{\text {CICR }}$ & $\boldsymbol{K}_{\text {IVC }}$ & $\boldsymbol{K}_{\text {CICR }}$ & $\boldsymbol{K}_{\text {IVC }}$ & $\boldsymbol{K}_{\text {CICR }}$ \\
\hline Vnukovo International Airport & 2.74 & 3.5 & 1.05 & 3,21 & 1.09 & 1.56 & 0.87 & 0.92 \\
\hline Volgograd International Airport & 16.65 & 7.33 & 43.65 & 76,71 & - & - & - & - \\
\hline Anapa Airport & - & - & 20.6 & 1,13 & 5.28 & 13.35 & 3.51 & 9.03 \\
\hline Pobedilovo Airport - Kirov & 8.18 & -7.37 & -17.61 & $-13,85$ & -8.06 & -7.99 & 12.2 & -4.54 \\
\hline Kazan International Airport & 1.94 & -2.6 & 11.05 & 0,2 & 13.82 & 6.03 & 25.49 & -225.07 \\
\hline Ulyanovsk Airport & 16.35 & 97.35 & 359.59 & 3267,59 & 1.23 & -0.42 & 1.2 & 1.76 \\
\hline Irkutsk International Airport & - & - & 9.58 & 2,39 & 8.55 & 9.89 & 13.01 & 12.83 \\
\hline Tolmachevo Airport & 3.15 & 5.03 & 7.78 & 8,64 & 6.74 & 5.87 & 7.19 & 7.08 \\
\hline Omsk Airport & 7.42 & 17.95 & 28.63 & 39,02 & 48.36 & 74.01 & $1,875.41$ & $2,145.95$ \\
\hline Vladivostok International Airport & 6.73 & 7.05 & 11.97 & 12,43 & 0.73 & 6.27 & -17.38 & 8.53 \\
\hline Khabarovsk Airport & 45.45 & 51.42 & 5.87 & 6,43 & 6.17 & 5.2 & 6.55 & 2.22 \\
\hline Yakutsk Airport & 34.6 & 52.96 & 4,487 & 10,278 & - & - & - & - \\
\hline
\end{tabular}

Note . Some companies have been operating without making any interest payment, thus impeding the assessment for the last period. Source : Authoring 
Table 5

A correlation of credit ratings and interest coverage ratios of large entities: S\&P's method

\begin{tabular}{ll}
\hline Bounds of interest coverage ratio & Rating \\
\hline$<0.2$ & D \\
\hline $0.2-0.65$ & C \\
\hline $0.65-0.8$ & CC \\
\hline $0.8-1.25$ & CCC \\
\hline $1.25-1.5$ & B- \\
\hline $1.5-1.75$ & B \\
\hline $1.75-2$ & B+ \\
\hline $2-2.25$ & BB \\
\hline $2.25-2.5$ & BB+ \\
\hline $2.5-3$ & BBB \\
\hline $3-4.25$ & A- \\
\hline $4.25-5.5$ & A \\
\hline $5.5-6.5$ & A+ \\
\hline $6.5-8.5$ & AA \\
\hline$>8.5$ & AAA \\
\hline
\end{tabular}

Source:[16]

Table 6

The range of the cash interest coverage ratio in large entities operating in airport operations

\begin{tabular}{lll}
\hline Range number & Range of the interest coverage ratio & $\begin{array}{l}\text { The number of CICR values within } \\
\text { the respective intervals }\end{array}$ \\
\hline 1 & Up to 3 & 6 \\
\hline 2 & $3-6$ & 5 \\
\hline 3 & $6-9$ & 7 \\
\hline 4 & $9-20$ & 4 \\
\hline 5 & Over 20 & 4 \\
\hline
\end{tabular}

Source : Authoring

Table 7

Grouping of entities ranked by cash interest coverage ratio

\begin{tabular}{llll}
\hline $\begin{array}{l}\text { Rating by } \\
\boldsymbol{K}_{C I C R}\end{array}$ & Range of $\boldsymbol{K}_{\text {CICR }}$ Values & $\boldsymbol{K}_{\text {CICR }}$ & Airport \\
\hline C & $<3$ & 1.56 & Vnukovo International Airport \\
\hline B & From 3 to 6 & 5.2 & Khabarovsk Airport \\
\cline { 2 - 4 } & & 5.87 & Tolmachevo International Airport \\
\hline BB & From 6 to 9 & 6.03 & Kazan International Airport \\
\hline A & From 9 to 20 & 6.27 & Vladivostok International Airport \\
\hline AA & Over 20 & 9.89 & Irkutsk International Airport \\
\hline
\end{tabular}

Source : Authoring

Please cite this article as: Laskina L.Yu. Expanding Analytical Capabilities of the Ratio Analysis of Entities' Solvency Through Cash Flows. Digest Finance, 2018, vol. 23, iss. 1, pp. 16-28. 


\section{Table 8}

Grouping of companies ranked by the interest coverage ratio

\begin{tabular}{llll}
\hline Rating by $\boldsymbol{K}_{\boldsymbol{W C}}$ & Range of $\boldsymbol{K}_{\boldsymbol{V C}}$ values & Values of $\boldsymbol{K}_{\boldsymbol{N C}}$ & Airport \\
\hline $\mathrm{D}$ & $<0.2$ & - & - \\
\hline $\mathrm{C}$ & $0.2-0.65$ & - & - \\
\hline $\mathrm{CC}$ & $0.65-0.8$ & 0.73 & Vladivostok International Airport \\
\hline CCC & $0.8-1.25$ & 1.09 & Vnukovo International Airport \\
\hline B- & $1.25-1.5$ & - & - \\
\hline B & $1.50-1.75$ & - & - \\
\hline B+ & $1.75-2$ & - & - \\
\hline BB & $2.00-2.25$ & - & - \\
\hline BB+ & $2.25-2.5$ & - & - \\
\hline BBB & $2.5-3$ & - & - \\
\hline A- & $3-4.25$ & - & - \\
\hline A & $4.25-5.5$ & - & - \\
\hline A+ & $5.5-6.5$ & 6.17 & Khabarovsk Airport \\
\hline AA & $6.5-8.5$ & 6.74 & Tolmachevo International Airport \\
\hline AAA & $>8.5$ & 8.55 & Irkutsk International Airport \\
\cline { 2 - 4 } & & 13.82 & Kazan International Airport \\
\cline { 2 - 4 } & & 48.36 & Omsk Airport \\
\hline
\end{tabular}

Source : Authoring

Figure 1

Trends in changes of the number of airports in Russia, 1991-2015

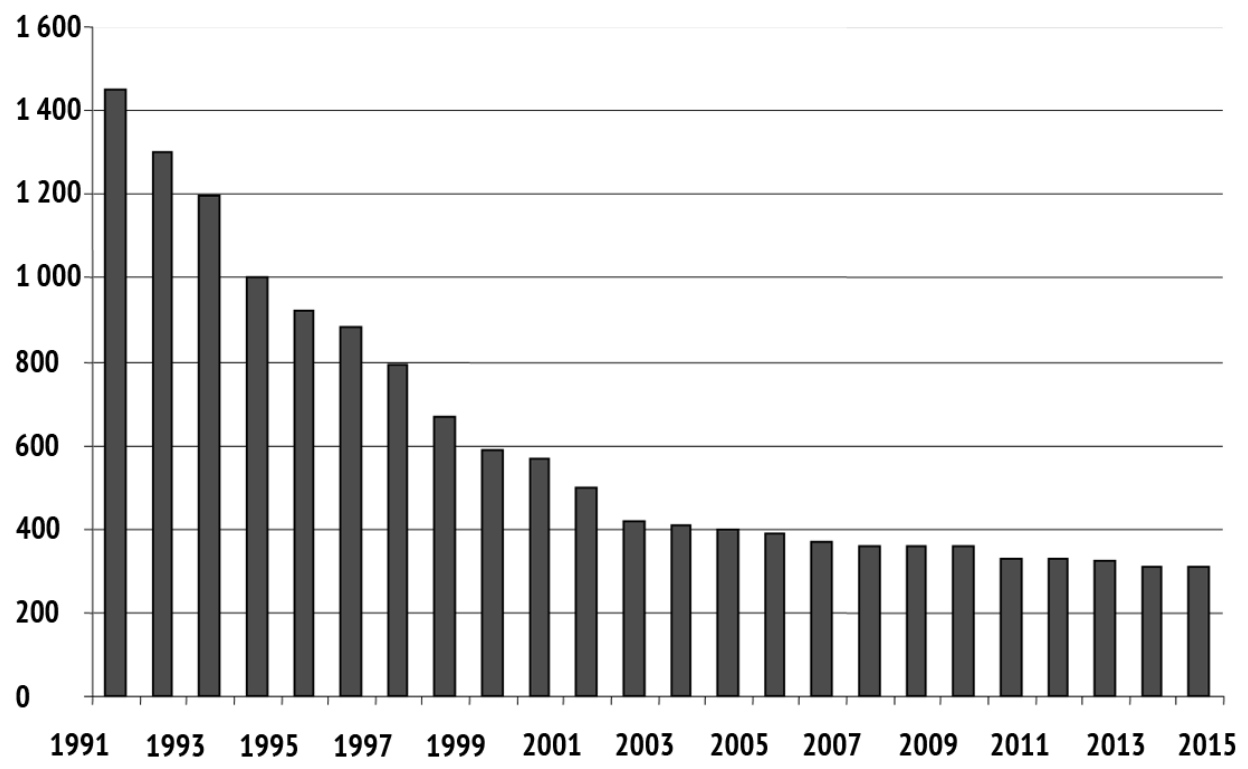

Source : Federal Air Transport Agency 


\section{Figure 2}

Trends in values of $K_{\text {curllqdt }}$ and $K_{C F}$ : Evidence from Vnukovo International Airport, 2011-2014

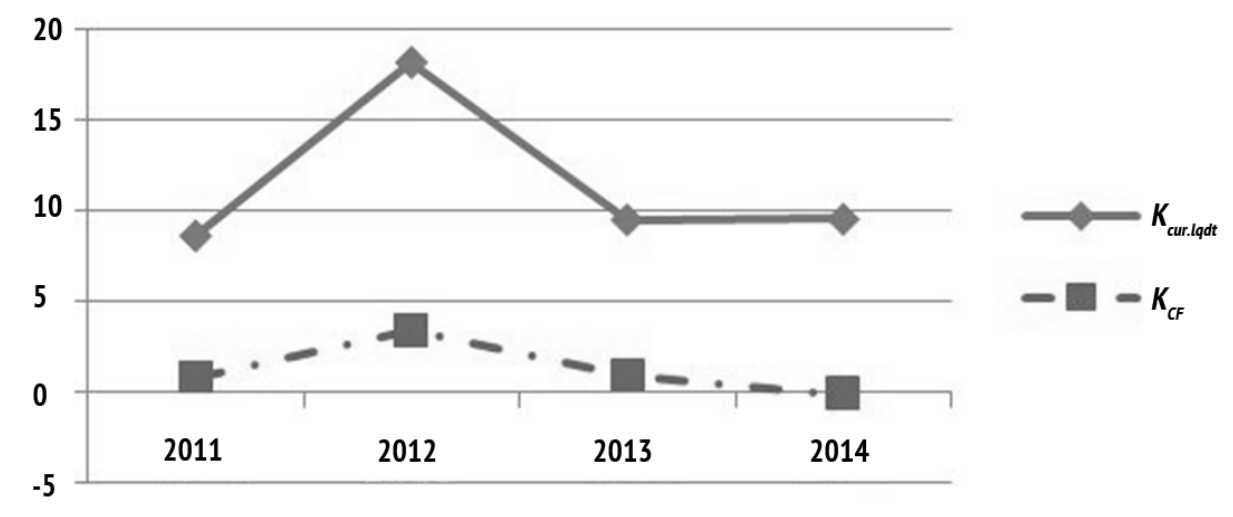

Source : Authoring

\section{Figure 3}

Trends in values of $K_{\text {curllqdt }}$ and $K_{C F}$ : Evidence from Ulyanovsk Airport, 2011-2014

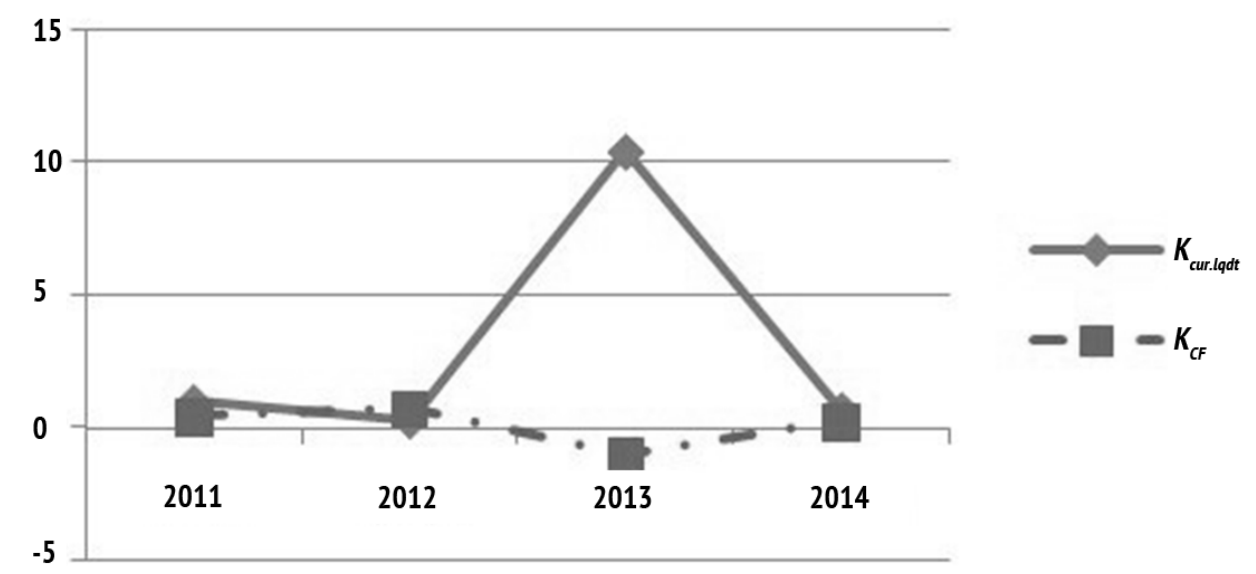

Source : Authoring 


\section{Figure 4}

Trends in values of $K_{I C C}$ and $K_{C I C R}$ : Evidence from Vnukovo International Airport, 2011-2014

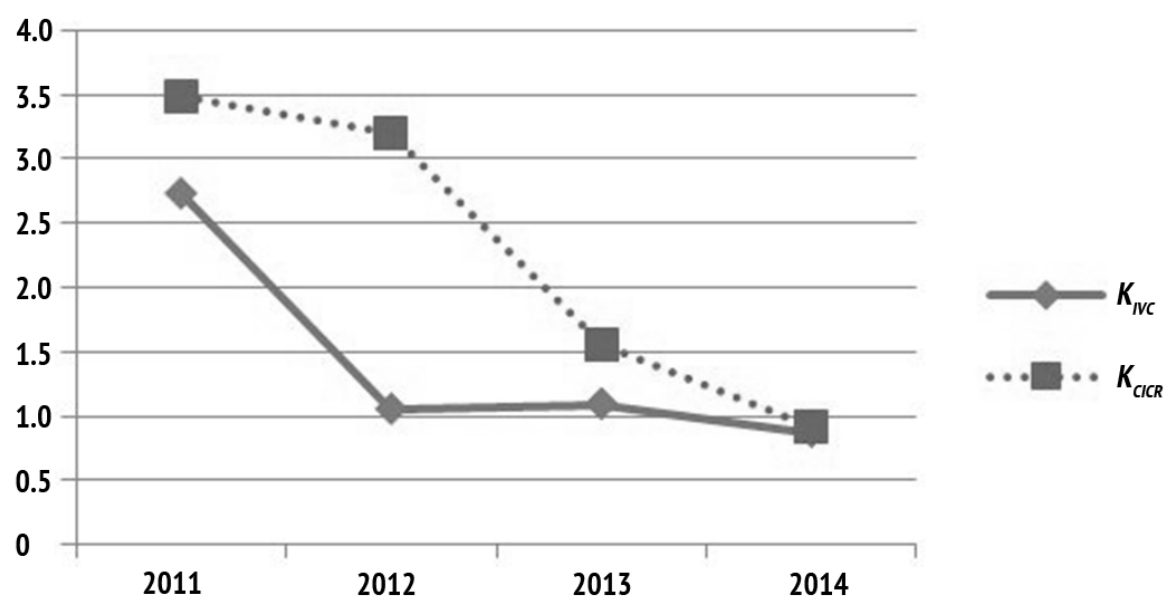

Source : Authoring

\section{Figure 5}

Trends in values of $K_{I V C}$ and $K_{C I C R}$ : Evidence from Vladivostok International Airport, 2011-2014

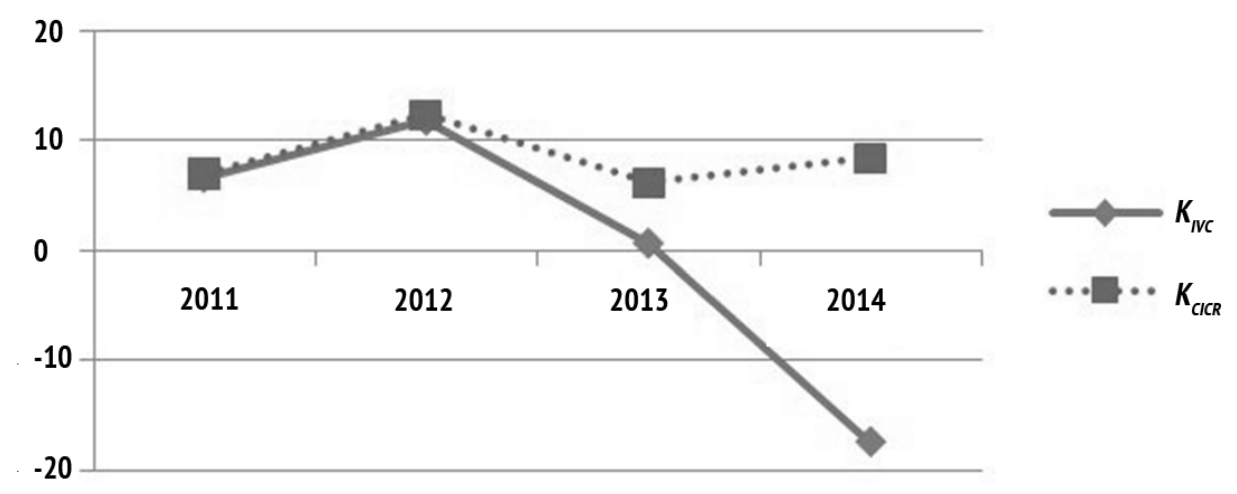

Source : Authoring 


\section{References}

1. Sorokina E.M. [Theoretical aspect of analysis of organization's financial solvency]. Izvestiya Irkutskoi gosudarstvennoi ekonomicheskoi akademii = Izvestiya of Irkutsk State Economics Academy, 2012, no. 2, pp. 80-86. (In Russ.)

2. Laskina L.Yu. [Capacity to pay as a measure of value creation]. Upravlencheskii uchet = Management Accounting, 2013, no. 10, pp. 47-54. (In Russ.)

3. Kemenov A.A. [Estimation of a management efficiency monetary streams of the building organization]. Finansovaya zhizn' = Financial Life, 2012, no. 2, pp. 47-53. (In Russ.)

4. Sverdlina E.B. [Monitoring of organization's financial standing]. Vestnik Omskogo universiteta. Ser.: Ekonomika= Herald of Omsk University. Series Economics, 2010, no. 3, pp. 154-159. (In Russ.)

5. Tsyrkunova T.A. [Application of normative levels and trend analysis to generate estimates of financial ratios]. ETAP: Ekonomicheskaya Teoriya, Analiz, Praktika = ETAP: Economic Theory, Analysis, Practice, 2011, no. 2, pp. 61-68. (In Russ.)

6. Laskina L.Yu., Vlasova M.S. [Comparative estimate of enterprise liquidity using traditional ratios and cash flow ratios]. Nauchnyi zhurnal NIU ITMO. Ser.: Ekonomika i ekologicheskii menedzhment, 2013, no. 2. (In Russ.) URL: http://economics.ihbt.ifmo.ru/file/article/7141.pdf

7. Vitsko E.A. [Analysis of Essence and Prospects of Forms of Settlements in Domestic and Foreign Economy between Business Entities]. Nauchnyi zhurnal NIU ITMO. Ser.: Ekonomika i ekologicheskii menedzhment, 2014, no. 3. (In Russ.) URL: http://economics.ihbt.ifmo.ru/file/article/10485.pdf

8. Cheremushkin S. [Assessing the financial condition of the company based on cash ratios]. Finansovyi menedzhment $=$ Financial Management, 2007, no. 5, pp. 11-22. (In Russ.)

9. Giacomino D.E., Mielke D.E. Cash Flows: Another Approach to Ratio Analysis. Journal of Accountancy, 1993, March, vol. 175, no. 3, pp. 55-58.

URL: https://www.questia.com/library/journal/1G1-13663207/cash-flows-another-approach-to-ratio-analysis

10. Kirkham R. Liquidity Analysis Using Cash Flow Ratios and Traditional Ratios: The Telecommunications Sector in Australia. Journal of New Business Ideas \& Trends, 2012, vol. 10, iss. 1, pp. 1-13.

URL: http://jnbit.org/upload/JNBIT_Kirkham_2012_1.pdf

11. Orlova T.S., Yaroshevich N.Yu. [Trends in the development of infrastructure sectors: The global airport industry case]. Upravlenie $=$ Management, 2013, no. 1, pp. 34-43. (In Russ.)

12. Varaksa A.M. [Comprehensive Approach to National Economy]. Nauchnye problemy transporta Sibiri i Dal'nego Vostoka = Scientific Problems of Transportation in Siberia and the Far East, 2015, no. 1, pp. 6-9. (In Russ.)

13. Stroganova V.I., Trunina V.F. [Areas of airport infrastructure development]. Molodoi uchenyi $=$ Young Scientist, 2011, vol. 1, no. 12, pp. 188-190. (In Russ.)

14. Eremin V.L., Kramarenko A.V. [Concessional mechanism as an efficient instrument of airports' infrastructure upgrade]. ETAP: Ekonomicheskaya Teoriya, Analiz, Praktika = ETAP: Economic Theory, Analysis, Practice, 2010, no. 4, pp. 106-116. (In Russ.)

15. Kramorenko M.I., Varaksa A.M. [The role of foreign investment in economic security of the federal districts of the Russian Federation]. Sibirskaya finansovaya shkola = Siberian Financial School, 2015, no. 6, pp. 71-74. (In Russ.) 
16. Damodaran A. Investitsionnaya otsenka: instrumenty i metody otsenki lyubykh aktivov [Investment Valuation: Tools and Techniques for Determining the Value of Any Asset]. Moscow, Al'pina Biznes Buks Publ., 2005, 1341 p.

17. Putikhin Yu.E., Vlasova M.S. [To the questions of the efficiency's analysis of investment projects. Assessment of negative cash flow]. Uchenye zapiski Sankt-Peterburgskogo universiteta upravleniya i ekonomiki = Scientific Notes of Saint-Petersburg University of Management and Economics, 2014, no. 1, pp. 14-21. (In Russ.)

18. Pogostinskaya N.N., Pogostinskii Yu.A., Vlasova M.S. [The factor analysis of dynamic standard models in the system of information support to management]. Izvestiya Mezhdunarodnoi akademii agrarnogo obrazovaniya = Journal of International Academy of Agrarian Education, 2012, vol. 2, no. 14, pp. 236-241. (In Russ.)

19. Laskina L.Yu., Smirnova O.Yu. [National credit rating agency as an alternative to the international rating agencies]. Uchenye zapiski Mezhdunarodnogo bankovskogo instituta = Proceedings of International Banking Institute, 2016, no. 17, pp. 56-63. (In Russ.)

20. Vlasova M.S., Laskina L.I., Silakova L.V. Estimating the Impact of Taxation on the Company's Strategic Sustainability. EACES Workshop: Financial Development in Transition and Post-Transition Countries. Serbia, EACES, 2015, pp. 131-139.

\section{Conflict-of-interest notification}

I, the author of this article, bindingly and explicitly declare of the partial and total lack of actual or potential conflict of interest with any other third party whatsoever, which may arise as a result of the publication of this article. This statement relates to the study, data collection and interpretation, writing and preparation of the article, and the decision to submit the manuscript for publication. 